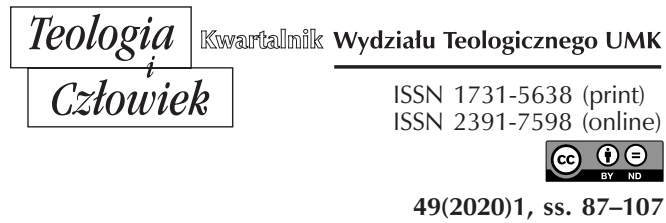

ANNA ZELLMA

UNIWERSYTET WARMIŃSKO-MAZURSKI W OLSZTYNIE

ANNA.ZELLMA@UWM.EDU.PL

ORCID 0000-0002-3612-3454

KS. WOJSŁAW WOJCIECH CZUPRYŃSKI

UNIWERSYTET WARMIŃSKO-MAZURSKI W OLSZTYNIE

CZUWOJ@WP.PL

ORCID 0000-0002-1541-2820

\title{
KORELACJA NAUCZANIA RELIGII Z KATECHEZĄ PARAFIALNĄ WE WSPÓŁCZESNYM DYSKURSIE POLSKICH KATECHETYKÓW
}

DOI: http://dx.doi.org/10.12775/TiCz.2020.005

Streszczenie. W działalności katechetycznej Kościoła, podejmowanej wśród dzieci i młodzieży ważne miejsce zajmuje integralność. To dlatego polscy badacze w dyskursie naukowym zwracają uwagę nie tylko na przekaz wiedzy i wychowanie, ale także na mistagogię. Uwzględniając przemiany społeczne, kulturowe i religijne, słusznie za istotną uznają korelację nauczania religii z katechezą parafialną. Zgodnie twierdzą, że kryzys tradycyjnego modelu inicjacji chrześcijańskiej, który uwidacznia się m.in. w kryzysie inicjacji chrześcijańskiej w rodzinie, w kryzysie duszpasterstwa sakramentalnego i w dydaktyzmie szkolnej lekcji religii implikuje potrzebę szczególnego dowartościowania komplementarności funkcji katechezy w posłudze Kościoła. Wymaga zwrócenia uwagi na ewangelizację w nauczaniu religii oraz na mistagogiczny i wspólnotowy wymiar katechezy parafialnej. Niezastąpioną rolę odgrywa tu katechumenat rodzinny.

Wyżej wymienione zagadnienia są wielokrotnie podejmowane przez polskich katechetyków. Zadanie pogłębionej refleksji staje się pilniejsze zwłaszcza dziś, w kontekście bardzo dynamicznie postępującej sekularyzacji i dechrystianizacji. Trzeba więc spojrzeć na nie z perspektywy rzetelnie przeprowadzanej diagnozy pastoralnej, by na tej podstawie wypracowywać nowe strategie korelacji nauczania religii z katechezą parafialną.

Słowa kluczowe: katechetyka; korelacja; nauczanie religii; katecheza parafialna; sekularyzacja; dechrystianizacja. 
Abstract. Correlation between religious instruction and parish catechesis in the contemporary discourse of Polish catechists. In the catechetical activity of the Church conducted among children and adolescents, a significant place is given to integrity. This is the reason why in the academic discourse Polish researchers focus not only on the transfer of knowledge and education, but also on mystagogy. Taking into account social, cultural and religious transformations, they rightly consider the correlation between religious instruction and parish catechesis to be important. The researchers unanimously claim that the crisis of the traditional Christian initiation model, which is manifested, among others, in the crisis of Christian initiation in the family, in the crisis of sacramental pastoral care and in the didacticism of religious instruction at school implies the need to particularly emphasize the value of the complementary function performed by catechesis in the Church service. This requires placing an emphasis on evangelization in religious instruction and the mystagogic and community dimension of parish catechesis, with family catechumenate playing an indispensable role.

The above-mentioned issues are often undertaken by Polish catechists. A deepened reflection seems to be even more urgent in contemporary times, in the context of dynamically progressing secularization and dechristianization. Therefore, it should be examined from the perspective of soundly conducted pastoral diagnosis to develop new strategies on this basis for correlating religious instruction with parish catechesis.

Keywords: catechetics; correlation; religious education; parish catechesis; secularization; dechristianization.

Charakterystyczną cechą współczesnej katechezy jest jej integralność. To dlatego w badaniach polskich katechetyków dominuje podejście holistyczne ${ }^{1}$. Zgodnie z dokumentami Soboru Watykańskiego II oraz posoborowymi dokumentami katechetycznymi badacze zwracają uwagę na różnorodne aspekty katechezy wiernej Bogu i człowiekowi. Uwzględniając przemiany społeczne, kulturowe i religijne, analizują kwestie dotyczące kształtu nauczania i wychowania $\mathrm{w}$ wierze dzieci, młodzieży i dorosłych $\mathrm{w}$ różnych środowiskach: rodzinie, szkole, parafii. Szczególną uwagę zwracają na relacje między nauczaniem religii a katechezą parafialną. Często analizują nie tylko zagadnienia organizacyjne i metodyczne, ale także merytoryczne. Wiążą je z programowaniem korelacji nauczania religii z katechezą parafialną ${ }^{2}$.

1 Zob. R. Murawski, R. Czekalski, J. Tochmański (oprac.), Bibliografia katechetyczna 1945-1995, Warszawa 1999; R. Czekalski, R. Murawski (oprac.), Bibliografia katechetyczna 1996-2000, Warszawa 2002; R. Czekalski, Bibliografia katechetyczna 2001-2010, Warszawa 2012.

2 Tamże. 
Analizy te, podejmowane od dawnych czasów, nigdy nie należały, i nadal nie należą, do łatwych. Wzbudzają bowiem wiele kontrowersji, zwłaszcza wśród praktyków - duszpasterzy i katechetów³. Jedną z istotnych przyczyn takiego stanu rzeczy jest rozdźwięk między teorią katechezy a praktyką pastoralną. Co więcej, prowadzony dyskurs często zdominowany jest aktualnymi problemami nauczania religii w szkole.

Celem analiz podjętych $\mathrm{w}$ niniejszym opracowaniu jest ukazanie korelacji nauczania religii $\mathrm{z}$ katechezą parafialną $\mathrm{w}$ obszarze pisemnych naukowych wywodów, podejmowanych przez współczesnych polskich katechetyków, które są nośnikiem określonych treści i sposobem prezentowania wyników badań ${ }^{4}$. Szczegółowe rozpatrywanie wyżej wymienionej problematyki na podstawie współczesnej polskiej literatury pozwoli nie tylko zaprezentować stan badań, lecz także dokonać ich wstępnej oceny i wskazać na kierunki dalszych poszukiwań. Najpierw zostaną zaprezentowane analizy współczesnych polskich katechetyków na temat kryzysu tradycyjnego modelu inicjacji chrześcijańskiej, który uwidacznia się m.in. w kryzysie inicjacji chrześcijańskiej w rodzinie, w kryzysie duszpasterstwa sakramentalnego i w dydaktyzmie szkolnej lekcji religii. W tym kontekście zwróci się uwagę na analizy poświęcone komplementarności funkcji katechezy w posłudze Kościoła, ze szczególnym uwzględnieniem ewangelizacyjnego wymiaru szkolnej lekcji religii, mistagogicznego i wspólnotowego wymiaru katechezy parafialnej oraz katechumentatu rodzinnego. $\mathrm{Na}$ podstawie zaprezentowanych badań zostaną ukazane kwestie, które do tej pory nie zyskały należnego zainteresowania polskich katechetyków, a które wydają się być interesujące i znaczące zarówno dla teorii, jak i dla praktyki katechetycznej.

\section{KRYZYS TRADYCYJNEGO MODELU INICJACJI CHRZEŚCIJAŃSKIEJ}

Sytuacja pastoralna Kościoła w Polsce prowadzi do konkluzji o potrzebie pilnego przesunięcia punktu ciężkości w duszpasterstwie, aby

3 Pisze o tym np. A. Potocki, O Kościele także socjologicznie, Warszawa 2017, passim.

${ }^{4}$ Zob. o definicji pojęcia "dyskurs” (łac. discursus) np. w: A. Podsiad, Słownik terminów i pojęć filozoficznych, Warszawa 2000, s. 201. 
religijność tradycyjną zastępować świadomym aktem wiary żywej i konsekwentnej. Nawet pobieżny ogląd rzeczywistości Kościoła daje prawo formułować twierdzenie, że życie wielu współczesnych chrześcijan nie jest dojrzałe. Ich wiara opiera się często bardziej na tradycji i zwyczajach, aniżeli na osobistej i osobowej relacji z Bogiem. Nigdy też tak naprawdę nie doświadczyli, czym jest odpuszczenie grzechów, nie poznali wartości chrześcijańskiego świadectwa, nie odczytali swojego chrześcijańskiego powołania ${ }^{5}$. Zasadniczym motywem jest uznanie niewystarczalności dotychczasowego duszpasterstwa. Źródłem zaś jest utracenie przez Kościół środowiska wychowawczego $\mathrm{w}$ dwóch najważniejszych przestrzeniach: rodzinie i parafii.

Statystyczna polska rodzina, która przez wieki wraz ze środowiskiem społecznym stanowiła swego rodzaju społeczny katechumenat, dziś już nie wypełnia swojej funkcji wdrażania do życia chrześcijańskiego i do życia we wspólnocie eklezjalnej ${ }^{6}$. Jej znaczenie dla chrześcijańskiej formacji jest nie do przecenienia. Istotnymi walorami środowiska rodzinnego są: naturalne więzi miłości, autorytet, spontaniczność, wspólnie spędzany czas, możliwość bezpośredniego wpływu poprzez świadectwo ${ }^{7}$. To wszystko stanowi niejako bazę psychologiczną, umożliwiającą nawiązanie osobowej i osobistej relacji z Bogiem. Dziecko formuje atmosfera, którą ono na co dzień oddycha, potrzebuje też wokół siebie nie tyle nauczycieli, co świadków. Rodzice pełnią wobec dzieci rolę podwójną. Są dla nich najważniejszym przykładem zachowań, a także pełnią rolę pośrednictwa w nawiązywaniu przez dzieci kontaktów z innymi podmiotami socjalizacji (rówieśnicy, szkoła, Kościół) . Wiara dziecka nie może się rozwinąć bez oparcia o wiarę i życie religijne najbliższego, codziennego otoczenia ${ }^{9}$.

${ }^{5}$ E. Alberich, Katecheza dzisiaj. Podręcznik katechetyki fundamentalnej, Warszawa 2003, s. 23-25.

${ }^{6} \mathrm{~J}$. Bagrowicz, Inicjacja i katechumenat jako zasada i metoda edukacji religijnej młodzieży, w: Funkcja inicjacyjna katechezy w Kościele współczesnym, red. K. Kantowski, Szczecin 2007, s. 186.

7 S. Dziekoński, Specyfika chrześcijańskiego wychowania $w$ rodzinie, w: Wychowanie chrześcijańskie. Między tradycją a współczesnościa, red. A. Rynio, Lublin 2007, s. 700-701.

8 Tamże.

9 Tamże. 
Dziś ojciec i matka coraz rzadziej uważają się za kompetentnych przekazicieli wiary. Dynamicznie poszerza się grono takich rodziców, dla których czymś naturalnym jest przenoszenie odpowiedzialności za chrześcijańską formację swoich dzieci na „urzędowych” przedstawicieli Kościoła: księży, katechetów ${ }^{10}$. W takiej perspektywie rola rodziców ma w najlepszym wypadku ograniczać się do posyłania dzieci na lekcje religii, wysyłania na niedzielną Eucharystię lub pilnowania odmawiania pacierza ${ }^{11}$.

Także w obszarze duszpasterstwa parafialnego dostrzega się znamiona kryzysu i formuje się postulaty zmiany jego koncepcji. Dostrzega się pilną potrzebę przejścia od duszpasterstwa zachowującego dotychczasowy styl o wyraźnym obliczu kultowym do duszpasterstwa ewangelizacyjnego i inicjacyjnego, określając ten nieodzowny proces mianem „nawrócenia pastoralnego"12. Duszpasterstwo ma przyjąć formę chrześcijańskiej inicjacji, ze wszystkimi jej elementami, takimi jak świadectwo, głoszenie kerygmatu, sakramenty, mistagogia, świadectwo miłości ${ }^{13}$.

Duszpasterstwo tradycyjne bardzo często ogranicza się do działań, które można scharakteryzować dwoma słowami: informacja i organizacja. Parafia stała się miejscem wielorakich akcji, często w żaden sposób ze sobą nie powiązanych. Brakuje całościowej wizji i zwartego programu duszpasterskiego. Wysiłek organizacyjny towarzyszący tym akcjom jest często niewspółmierny do mizernych efektów duszpasterskich. „Coraz większa ilość oddanych sprawie Chrystusa i Kościoła kapłanów oraz ich świeckich współpracowników odczuwa niedosyt i niewystarczalność dotychczasowego podejścia duszpasterstwa i apostolstwa. Jest to podejście wybitnie aktywistyczne, koncentrujące się wokół całego szeregu akcji i w nich się wyczerpujące. Na przykład jak zapewnić wystarczającą fre-

10 A. Offmański, Katechumenat pochrzcielny wzorcem nauczania religii i katechezy ewangelizacyjnej, w: Septuaginta pedagogiczno-katechetyczna, red. A. Walulik, J. Mółka, Kraków 2017, s. 697.

${ }^{11}$ K. Koseła, Religia przy tablicy - postawy wobec lekcji religii w szkołach, w: Szkoła czy parafia? Nauka religii $w$ szkole $w$ świetle badań empirycznych, red. K. Kiciński. K. Koseła, W. Pawlik, Kraków 1995, s. 93-94.

${ }^{12}$ K. Misiaszek, Mistagogia w katechezie, w: Mistagogia a duchowość, red. A. Żądło, Katowice 2004, s. 87.

13 Tamże. 
kwencję na nauce religii, jak nauczyć ludzi modlić się wspólnie, śpiewać na mszy świętej?"14.

Współczesnej parafii, jak zgodnie twierdzą katechetycy, można postawić kilka zarzutów. W obszarze katechetycznym brakuje realizacji katechezy parafialnej i jednolitych trwałych rozwiązań współpracy z rodziną i szkołą. W Dyrektorium katechetycznym Kościoła katolickiego w Polsce wyraźnie mówi się o potrzebie równoległej i wzajemnie dla siebie komplementarnej katechezy szkolnej i parafialnej ${ }^{15}$. Określa się tam szkolne nauczanie religii jako „część katechezy” lub „specyficzną formę katechezy" ${ }^{16}$, jednakże tych dwóch procesów chrześcijańskiej formacji nie utożsamia się. Wyraźnie też trzeba stwierdzić, że poza przygotowaniem do I Komunii świętej oraz do bierzmowania, w przestrzeni parafii nie ma innej formy systematycznej katechezy ${ }^{17}$. Podkreśla się, że ten rodzaj katechezy parafialnej w praktyce Kościoła w Polsce ma często charakter okazjonalny, ograniczony do niewielu spotkań i często przypomina bardziej instruktaż techniczny niż pełną katechezę wtajemniczającą w sakramenty Kościoła ${ }^{18}$. Tadeusz Panuś zauważa: „gdy zapytamy młodych: «z czym ci się kojarzy katecheza?». Odpowiedź jest jedna: «ze szkołą». Gdy zapytamy zaś, z czym ci się kojarzy parafia, raczej nie usłyszymy, że z katechezą. Dla młodzieży parafia przestała być miejscem katechezy"19. W ocenie Andrzeja Potockiego, najbardziej bolesną konsekwencją powrotu religii do szkół jest osłabienie więzi młodego pokolenia z parafią, czego wyrazem jest znaczący spadek praktyk religijnych w tej grupie wiekowej ${ }^{20}$.

${ }^{14}$ F. Blachnicki, Formacja stużby liturgicznej jako jedna $z$ form młodzieżowego deuterokatechumenatu w parafii, w: Katechumenat. Wspólnoty formacyjne we wspólnocie lokalnej, Biblioteczka animatora, z. 2, Krościenko 2002, s. 28-29.

${ }^{15}$ Konferencja Episkopatu Polski, Dyrektorium katechetyczne Kościoła katolickiego $w$ Polsce, Kraków 2001, 13, 106 (odtąd: PDK)

16 Tamże, 82.

${ }^{17}$ H. Iwaniuk, Nauka religii w szkole a katecheza parafialna, „Ateneum Kapłańskie" 96 (2004) z. 571, s. 463.

${ }^{18}$ K. Misiaszek, Koncepcja nauczania religii katolickiej w publicznej szkole polskiej, Warszawa 2010, s. 221.

19 T. Panuś, Potrzeba katechezy parafialnej, „Ateneum Kapłańskie” 96 (2004) Z. 573, s. 220 .

20 A. Potocki, Katecheza między niebem a ziemia - między parafia a szkoła, „Katecheta” 45 (2001) nr 2, s. 14. 
Janusz Mastalski pisze wprost: „W efekcie powrotu religii do szkół obawy związane ze zjawiskiem wyprowadzenia młodzieży i dzieci z parafii stały się w wielu środowiskach parafialnych faktem!"21. Kiedyś punkty katechetyczne stanowiły dla młodzieży funkcję pomostu z własną parafią; były miejscem spotkania i doświadczenia działających we wspólnocie Kościoła parafialnego ruchów i wspólnot modlitewnych.

Brakuje także systematycznej katechezy dorosłych i wypracowanych form współpracy ze środowiskiem rodziców, nauczycieli i wychowawców. Nienajlepiej przedstawia się także współpraca parafii ze szkołą, ograniczająca się często jedynie do organizacji szkolnych rekolekcji wielkopostnych ${ }^{22}$. Trzeba również stwierdzić, że przygotowujący się do chrześcijaństwa nie są objęci należytą troską. Brakuje wnikliwego zbadania motywacji kandydata. Formacja jest krótka, prowadzona dowolnie, co zamiast budzenia świadomości osobistego i osobowego spotkania z Chrystusem rodzi poczucie spełniania formalności. Takie działania są szkodliwe, tworzą bowiem chrześcijan pozornych, naiwnych lub traktujących religię magicznie i utwierdzają przekonanie o takim właśnie chrześcijaństwie ${ }^{23}$. Można zatem postawić wniosek, że we współczesnym życiu Kościoła, w tym także w parafii, nie ma faktycznie działającej instytucji katechumenatu, w której w sposób pełny i autentyczny dokonywałby się proces inicjacji do życia eklezjalnego.

Uwarunkowania obecnego czasu, naznaczonego kryzysem wiary, ideowym pluralizmem, permisywizmem moralnym i dynamicznie postępującym procesem sekularyzmu, stanowią wyzwanie, aby szukać bardziej skutecznych form pracy duszpasterskiej i wychowawczej. Niezrozumiałym wydaje się fakt, że szkolne nauczanie religii dzieci i młodzieży, nacechowane wielorakimi słabościami i nieskutecznością, stanowi dla współczesnego Kościoła podstawowy obszar urzeczywistniania chrześcijańskiej formacji² ${ }^{2}$.

${ }^{21} \mathrm{~J}$. Mastalski, Grupy, stowarzyszenia i ruchy religijne dla młodzieży w służbie katechezy, „Ateneum Kapłańskie” 96 (2004) z. 573, s. 287.

22 S. Dziekoński, Korelacja wychowania w rodzinie, parafi, szkole - potrzeba i możliwości, w: Rodzina - Szkoła - Kościół. Korelacja i dialog, red. P. Tomasik, Warszawa 2003, s. 45.

${ }^{23}$ F. Pełka, Uwarunkowania społeczne katechumenatu, „Ateneum Kapłańskie” 70 (1977), s. 216-220.

${ }^{24}$ K. Misiaszek, Koncepcja nauczania religii katolickiej w publicznej szkole polskiej, 
Wielu autorów jest zdania, że polska forma nauczania religii w szkole nie wystarcza do pełnej formacji chrześcijańskiej, nie jest ona w stanie zrealizować integralnego wtajemniczenia, przez co domaga się uzupełnienia poprzez parafialne inicjatywy katechetyczne ${ }^{25}$. Stwierdza się dobitnie: naiwnością jest twierdzenie, że edukacja religijna w szkole wystarczy dla rozwoju i utrzymania wiary. Człowiek dorasta do dojrzałych postaw religijno-moralnych przez partycypację w postawach religijno-moralnych ludzi dorosłych. Sam przekaz doktryny wiary, a nawet ukazywanie właściwych postaw moralnych na szkolnej lekcji religii nie wystarczy. Ten model nauczania religii był uzasadniony w czasach, kiedy uczniowie pochodzili $z$ rodzin przenikniętych autentycznym duchem wiary i religijną atmosferą. Z pewną dozą ironii można stwierdzić, że tacy uczniowie byli wierzący nie dzięki, ale mimo katechizacji, polegającej na memoryzacji doktryny wiary i teologicznych schematach katechizmowych. Szkolny katechumenat pozbawiony jest bowiem możliwości najważniejszej funkcji katechezy, jaką jest chrześcijańskie wtajemniczenie. Edukacja religijna w szkole ma sens tylko wtedy, gdy będzie pogłębiana w innych środowiskach ${ }^{26}$.

Zwraca się uwagę na szereg powodów, które uniemożliwiają skuteczny przekaz orędzia wiary w szkolnym nauczaniu religii. Po pierwsze, kontekst szkoły choć z jednej strony dowartościowuje element poznawczy i w jakimś stopniu wychowawczy, z drugiej uniemożliwia realizowanie funkcji wtajemniczenia chrześcijańskiego, najbardziej istotnej dla tożsamości i oryginalności chrześcijańskiej formacji. Po wtóre, szkoła publiczna nigdy nie będzie wspólnotą eklezjalną, czyli nigdy nie będzie mogła pełnić naturalnego środowiska katechumenalnego ${ }^{27}$. Kryterium kompletowania klasy szkolnej, w odróżnieniu od grup formacyjnych i katechetycznych w parafii, jest całkowicie akonfesyjne, a motywy uczęszczania na szkolne

s. 220-221; por. S. Dziekoński, Katecheza inicjacyjna w Polsce - rzeczywistość i oczekiwania, w: Funkcja inicjacyjna katechezy w Kościele współczesnym, red. K. Kantowski, Szczecin 2007, s. 101.

${ }^{25}$ K. Misiaszek, Katecheza parafialna - rzeczywistość i oczekiwania, w: Komunikacja wiary w trzecim tysiącleciu, red. S. Dziekoński, Olecko 2000, s. 63-74; A. Potocki, Katecheza w szkole jako problem duszpasterski, „Homo Dei” 62 (1993) nr 3, s. 48-59.

${ }^{26}$ R. Chałupniak, Katecheza w szkole czy poza szkoła?, „Paedagogia Christiana” 2012, nr 1, s. 178.

${ }^{27}$ K. Misiaszek, Mistagogia w katechezie, s. 87. 
lekcje religii bardzo rozmaite. W klasie szkolnej można wyróżnić zasadniczo trzy grupy: uczniowie religijnie zaangażowani (często członkowie jakichś wspólnot młodzieży katolickiej), uczniowie indyferentni, poszukujący, wątpiący o chwiejnej wierze i w końcu uczniowie zagubieni, którzy uważają się za niewierzących i ateistów ${ }^{28}$. Wobec tych trzech grup nauczanie religii pragnie realizować różnorodne funkcje: ewangelizacji lub właściwej katechezy. Nie zawsze jednak jest jasne, jak dokonywać ewangelizacji w szkole. Na marginesie należy też dodać, że funkcjonujące przez długi czas podręczniki do lekcji religii błędnie zakładały pewną jednorodność katechizowanych, a tym samym w niewielkim stopniu stanowiły rzeczywistą pomoc dydaktyczną ${ }^{29}$. Jak zauważa Kazimierz Misiaszek, brak oddzielenia pojęć «katecheza» $\mathrm{i}$ «szkolne nauczanie religii» ma swoje istotne konsekwencje. To nie do końca uzasadnione utożsamienie przyczynia się do powstawania niepotrzebnych konfrontacji między szkołą i katechezą, odwleka poszukiwanie rozwiązań systemowych w postaci nowych programów nauczania i wprowadzenia rzeczywistej katechezy parafialnej $^{30}$.

\section{KOMPLEMENTARNOŚĆ FUNKCJI KATECHEZY W POSŁUDZE KOŚClOŁA}

Wyżej opisany kryzys tradycyjnego modelu inicjacji chrześcijańskiej, zdaniem polskich katechetyków, uzasadnia potrzebę zintensyfikowania działań związanych z korelacją nauczania religii z edukacją szkolną ${ }^{31}$. Rozpatrując szczegółowe kwestie, badacze słusznie odwołują

${ }^{28}$ Jak zauważa A. Offmański: „nauczyciele religii, ale też i badania empiryczne jednoznacznie stwierdzają, że znaczny odsetek młodego pokolenia Polaków nawet przychodzących na szkolne lekcje religii to osoby niewierzące, a przynajmniej nieświadome tego, co się stało w dniu ich chrztu, który przyjęli bez swojej świadomości i wiary, a u podstaw której też nie zawsze była dojrzała osobowa rodziców czy opiekunów”. Tenże, Katechumenat pochrzcielny..., s. 697.

${ }^{29}$ H. Iwaniuk, Nauka religii w szkole a katecheza parafialna, s. 452-453.

${ }^{30}$ K. Misiaszek, Potrzeby i możliwości wprowadzenia elementów ewangelizacji do nauczania religii $w$ szkole, w: Katecheza ewangelizacyjna $w$ rodzinie, parafi, szkole, red. S. Dziekoński, Warszawa 2002, s. 173-184.

${ }^{31}$ R. Chałupniak, Katecheza w szkole czy poza szkoła?, s. 178; W. Czupryński, 
się do katechetycznych dokumentów Kościoła ${ }^{32}$. Zwracają szczególną uwagę na ewangelizacyjny wymiar szkolnej lekcji religii ${ }^{33}$. Podkreślają przy tym ścisły związek nowej ewangelizacji w środowisku szkolnym z całym posłannictwem katechetycznym Kościoła, które „zmierza do wychowania chrześcijan w poczuciu ich trojakiej tożsamości: jako ludzi ochrzczonych, jako wierzących i jako członków Kościoła”34. Za autorami dokumentów katechetycznych zwracają uwagę na potrzebę takiego głoszenia Dobrej Nowiny, „by docierała ona do umysłu uczniów właśnie na samym terenie ich nauki i by cała ich kultura została zharmonizowana w blaskach światła wiary" ${ }^{35}$. Wśród uczestników szkolnych lekcji religii są bowiem osoby, które chociaż zostały ochrzczone, a nawet przyjęły inne sakramenty, na pewnym etapie drogi życiowej utraciły sens żywej wiary, oddaliły się od wspólnoty Kościoła i zaniechały praktyk religijnych ${ }^{36}$ „albo wprost nie uważają się już za członków Kościoła, prowadząc życie dalekie od Chrystusa i od Jego Ewangelii” ${ }^{37}$. Wielu uczniów deklaruje

Odnowa parafii i duszpasterstwa. Deuterokatechumenalna koncepcja chrześcijańskiej formacji w myśli i dziele ks. Franciszka Blachnickiego, Olsztyn 2011, passim.

${ }^{32}$ W. Kujawin, Parafialne duszpasterstwo katechetyczne $w$ optyce magisterium Kościoła, „Łódzkie Studia Teologiczne” 23 (2014), s. 25-37; W. Lechów, Ku odnowie katechezy inicjacji chrześcijańskiej w parafii, „Studia Paradyskie”, 27 (2017), s. 53-71; R. Murawski, Działania katechetyczne w parafii w świetle Dyrektorium Ogólnego i Polskiego, w: Przesłanie dokumentów katechetycznych Kościoła w Polsce, red. S. Dziekoński, Warszawa 2002, 55-70; A. Offmański, Model katechezy ewangelizacyjnej w dokumentach Kościoła, w: Ewangelizować czy katechizować?, red. S. Dziekoński, Warszawa 2002, s. $53-72$.

33 Zob. np. P. Mąkosa, Ewangelizacyjny wymiar katechezy [online], [dostęp: 12.01.2019 r.], s. 1-10, <https://depot.ceon.pl/bitstream/handle/123456789/3627/Ewangelizacyjny\%20wymiar\%20katechezy.pdf?sequence=3>; P. Tomasik, Ewangelizacyjne formy katechezy w kontekście wezwania do nawrócenia, „Studia Theologica Varsaviensia” 2 (2014), s. 103-129.

34 PDK 56.

35 P. Mąkosa (red.), Katecheza ewangelizacyjna. Poszukiwania koncepcji, Lublin 2010, passim; E. Młyńska, Ewangelizacyjny wymiar katechezy parafialnej, w: Katecheza ewangelizacyjna $w$ rodzinie, parafi, szkole, s. 115-138.

${ }^{36}$ A. Potocki, Ewangelizacyjna katecheza młodzieżowa z perspektywy paradygmatów teologii pastoralnej, w: Katecheza ewangelizacyjna. Poszukiwania koncepcji, s. 123-144; por. P. Mąkosa (red.), Nowa ewangelizacja w nowej katechezie, Rzeszów 2013, passim.

37 RM 33. 
obojętność religijną ${ }^{38}$ i osłabienie uczestnictwa w niedzielnej mszy św. ${ }^{39}$ Ich rodzice nie wykazują zbytniego zainteresowania formacją religijną swoich dzieci w szkole ${ }^{40}$. W związku z powyższymi jakże trafnymi spostrzeżeniami słusznie polscy katechetycy dostrzegają potrzebę głoszenia Dobrej Nowiny i składania świadectwa wiary wobec uczestników lekcji religii ${ }^{41}$. Wymienione działania ewangelizacyjne poszerzają o grono pedagogiczne, rodziców i pracowników administracyjnych. Zdaniem polskich katechetyków lekcje religii stają się „podstawową formą kontaktu z Ewangelią, a katecheta podstawowym, instytucjonalnym łącznikiem z Kościołem"42. Ma doprowadzić adresatów do spotkania z Jezusem Chrystusem, nawiązania z Nim osobowej więzi oraz przylgnięcia do Niego, nawrócenia serca, ożywienia ducha wiary, odkrycia sensu życia i swojego miejsca we wspólnocie Kościoła oraz wywołania nowej gorliwości apostolskiej ${ }^{43}$. Także w tym kontekście polscy katechetycy słusznie wskazują na integralne powiązanie ewangelizacji z wychowaniem ${ }^{44}$. „Ewangelizacja akcentuje bowiem znaczenie Chrystusa w doświadczeniu wiary, inicjuje i kształtuje więź z Chrystusem” 45 oraz „podkreśla personalny charakter wychowania, bowiem jego zadaniem jest budowanie więzi miedzy Chrystusem i człowiekiem oraz miedzy ludźmi na fundamencie trwałych wartości, wydobywających prawdę o niepowtarzalności i godności osoby

38 Tamże 3-5.

39 Zob. np. A. Potocki, Ewangelizacyjna katecheza młodzieżowa $z$ perspektywy paradygmatów teologii pastoralnej, s. 138-143.

${ }^{40}$ K. Misiaszek, Potrzeby i możliwości wprowadzenia elementów ewangelizacji..., s. 174 .

${ }^{41}$ Tamże; P. Tomasik, Możliwości ewangelizacji w szkolnym nauczaniu religii, w: Katecheza ewangelizacyjna. Poszukiwania koncepcji, s. 73 i nn.

${ }^{42}$ K. Misiaszek, Potrzeby i możliwości wprowadzenia elementów ewangelizacji..., s. 174 .

${ }^{43}$ J. Kochel, Lekcja religii szansq dla ewangelizacji, „Polonia Sacra” 22 (2018) nr 2 s. 19-39; P. Tomasik, Lekcja religii katolickiej: wybór między dwiema skrajnościami, „Katecheta” 43 (1999) nr 7-8 s. 94; tenże, Katecheza Kościoła w Polsce wobec nowej ewangelizacji, „Verbum Vitae” 21 (2012), s. 273-296.

${ }^{44}$ R. Chałupniak, Katecheza w stużbie przekazu i formacji wiary. Nowa ewangelizacja (w nowej) katechezie, „Katecheta” 56 (2012) nr 7-8, s. 4-16.

45 A. Potocki, Ewangelizacyjna katecheza młodzieżowa..., s. 142-143. 
ludzkiej"46. Ta ostatnia kwestia koresponduje z personalistycznym charakterem szkolnego wychowania, w którym zwraca się uwagę na wspieranie uczniów w holistycznym rozwoju. Cele wychowawcze współczesnej szkoły, jak wielokrotnie zauważają to polscy katechetycy, nie mogą pomijać wychowania religijnego i ewangelizacji ${ }^{47}$. Co więcej, właśnie ewangelizacja podejmowana w ramach wyznaniowej lekcji religii umożliwia wspieranie uczniów w nabywaniu umiejętności twórczego i samodzielnego myślenia oraz wdraża do odpowiedzialnego działania. Dokonuje się to, jak trafnie zauważają i kompetentnie dowodzą polscy katechetycy, m.in. we właściwie rozumianych działaniach korelacyjnych z edukacją szkolną.

Ewangelizacja podejmowana przez nauczyciela religii w środowisku szkolnym stanowi punkt wyjścia w procesie prowadzeniu uczestników lekcji religii do rozwoju wiary, który dokonuje się we wspólnocie Kościoła - m.in. w ramach katechezy parafialnej (w tym także katechezy wtajemniczającej i sakramentalnej) $)^{48}$. Słusznie zatem polscy katechetycy wiele uwagi poświęcają działaniom katechetycznym, które wprowadzają w głębsze rozumienie liturgii oraz celebracjom i uczestnictwu w niej ${ }^{49}$. Powołując się na dokumenty Kościoła, wielokrotnie przypominają, że katecheza parafialna jest integralnie powiązana $\mathrm{z}$ mistagogią, która ma na celu pogłębienie życia sakramentalnego i życia we wspólnocie ${ }^{50}$. Zauważają, że wrażliwość katechetyczna w Polsce ciągle zbyt słabo akcentuje mistagogiczny wymiar katechezy ${ }^{51}$, a w całej koncepcji inicjacji chrześcijańskiej dochodzi do

${ }^{46}$ P. Tomasik, Możliwości ewangelizacji w szkolnym nauczaniu religii, s. 75.

${ }^{47}$ J. Kochel, Lekcja religii szansq dla ewangelizacji, s. 19 i nn; S. Łabendowicz, Wychowanie chrześcijańskie w katechezie szkolnej, „Roczniki Pedagogiczne” 8 (2016) nr 2, s. 49-76.

${ }^{48}$ K. Kantowski (red.), Katecheza w parafii. Poszukiwanie tożsamości, Warszawa 2004, passim.

${ }^{49}$ M. Zając (red.), Katecheza $w$ parafii, Lublin 2016, passim.

${ }^{50}$ R. Buchta, Mistagogia w polskiej refleksji i praktyce katechetyczno-duszpasterskiej po II Soborze Watykańskim, Katowice 2017, passim.

${ }^{51}$ K. Misiaszek zauważa: „w obecnej sytuacji polskiej z dużym trudem udaje się osiągnąć cele formacji chrześcijańskiej, i to nie tylko w jej wymiarze mistagogicznym, ale i ogólnym. Nie sprzyja temu z pewnością nauczanie religii w szkole publicznej, głównie z tego powodu, że szkoła nie jest wspólnotą eklezjalną w ścisłym sensie, a więc nie tworzy odpowiednich warunków do zrealizowania w pełni wymiaru inicjacyjnego. Ponadto obecność lekcji religii w obszarze edukacji obowiązkowej sprawia, że dowartościowuje 
„swoistego pomieszania celów ze środkami, w tym znaczeniu, że sakramenty traktuje się poniekąd jako cele same w sobie, gdy tymczasem są one środkami wspomagającymi doskonalenie życia chrześcijańskiego" ${ }^{52}$. Innym postulatem, wysuwanym pod adresem współczesnej katechezy, jest potrzeba takiej formacji samych katechetów, aby nabyli oni umiejętność egzystencjalnej interpretacji orędzia zbawczego, czyli zdolności wydobywania jego sensu i znaczenia dla zwykłej codzienności ${ }^{53}$.

Twierdzą, że „W obecnej sytuacji polskiej z dużym trudem udaje się osiągnąć cele formacji chrześcijańskiej, nie tylko tej w wymiarze mistagogicznym, ale i ogólnym” ${ }^{4}$. Zdaniem polskich katechetyków „nie sprzyja temu z pewnością nauczanie religii w szkole publicznej, głównie z racji faktu, że szkoła nie jest w ścisłym znaczeniu tego terminu wspólnotą eklezjalną, a tym samym nie tworzy odpowiednich warunków do zrealizowania pełnego wymiaru inicjacyjnego ${ }^{55}$. Ponadto obecność lekcji religii w obszarze obowiązkowej edukacji sprawia, że dowartościowuje najbardziej ten rys, jaki jest właściwy szkole (poznawczy i wychowawczy), jakby zapominając o swoim wymiarze wtajemniczenia, decydującym bodaj w największym stopniu o tożsamości i oryginalności chrześcijańskiej formacji. Tym samym szkolne nauczanie religii nie jest także w stanie być pełną katechezą eklezjalną ${ }^{56}$. Konsekwentnie zatem polscy katechetycy twierdzą, że w tej sytuacji jedynie rzetelnie prowadzona katecheza parafialna może wypełnić wszystkie założenia kościelnej katechezy ${ }^{57}$. Wspólnota

najbardziej ten ich cel, jaki jest właściwy szkole (a więc poznawczy i wychowawczy), jakby zapominając o wymiarze wtajemniczenia, najważniejszym dla tożsamości i oryginalności formowania chrześcijańskiego". Tenże, Mistagogia w katechezie, s. 87.

${ }^{52}$ Tamże, s. 88; K. Misiaszek zwraca też uwagę na konieczność odejścia od błędnych i szkodliwych dla formacji wiernych sformułowań językowych, takich jak, np. „przygotowanie do sakramentów”, „przygotowanie do pierwszej Komunii świętej”. Tamże.

53 Tamże, s. 89.

54 Tamże.

${ }_{55}$ R. Czekalski, Katecheza komunikacja wiary, Płock 2006, s. 86-101.

56 Tamże.

57 P. Mąkosa, Systematyczna katecheza parafialna dzieci i młodzieży. Motywacja $i$ realizacja [online], [dostęp: 22.01 .2019 r.], s. 1-39, <https://depot.ceon.pl/bitstream/ handle/123456789/3177/Systematyczna\%20katecheza\%20parafialna\%20dzieci\%20i\%20 m\%C5\%82odzie\%C5\%BCy.\%20Motywacja\%20i\%20realizacja.pdf?sequence=1>. 
chrześcijańska (eklezjalna) jest bowiem - obok rodziny - pierwszym i podstawowym podmiotem, a zarazem środowiskiem katechetycznym ${ }^{58}$. Biorąc pod uwagę stwierdzenia zawarte w dokumentach katechetycznych, trafnie dowodzą, że wspólnota chrześcijańska (i każda osoba, która do niej należy) jest odpowiedzialna za jakość katechezy parafialnej ${ }^{59}$. W tym kontekście rzetelnie opisują podstawowe zadania wspólnoty parafialnej względem katechezy i katechizowanych ${ }^{60}$. Słusznie zwracają uwagę na „tworzenie odpowiednich warunków rozwoju życia chrześcijańskiego, głównie poprzez autentyczny przykład życia chrześcijańskiego, dawanie świadectwa, ożywianie wspólnoty chrześcijańskiej [...]"61, troskę o programowanie i konkretne formy działalności katechetycznej w parafii. Akcentują też znaczenie katechezy dorosłych, ewangelizację dokonującą się w ramach wyznaniowej lekcji religii oraz na znaczenie rekolekcji szkolnych i pielgrzymek ${ }^{62}$. Domagają się większego zaangażowania nie tylko urzędowych katechetów (np. biskupów, kapłanów, katechetów świeckich), ale także rodziców, animatorów ze wspólnot i wszystkich wiernych, którzy przez chrzest zostali włączeni do wspólnoty Kościoła ${ }^{63}$. Wielokrotnie odwołują się do historii katechezy ${ }^{64}$. Szukają tu uzasadnienia dla działalności katechetycznej w parafii, co zasługuje na szczególną uwagę. Refleksja nad aktualną sytuacją korelacji nauczania religii $\mathrm{z}$ katechezą parafialną nie może być bowiem oderwana od przeszłości. W świetle tego, jak Kościół

${ }^{58}$ K. Misiaszek, Wspólnota chrześcijańska (parafia) jako podmiot katechezy, w: Katecheza w parafii. Poszukiwanie tożsamości, s. 17-27.

59 Tamże; zob. także i por. T. Panuś, Parafia uprzywilejowanym miejscem dla katechezy przygotowujacej do sakramentu dojrzałości chrześcijańskiej. Doświadczenia krakowskie, w: Dzisiejszy bierzmowany. Problemy i wyzwania, red. J. Stala, Kielce 2005, s. $257-280$.

${ }^{60}$ K. Misiaszek, Co z katecheza parafialna w Kościele w Polsce?, „Studia Pastoralne" 13 (2017) nr 13, s. 87-97; A. Potocki, Parafia - podmiotem i miejscem katechezy, „Perspectiva: Legnickie Studia Teologiczno-Historyczne” 5 (2006) nr 2, s. 84-100.

${ }^{61}$ P. Mąkosa, Systematyczna katecheza parafialna dzieci i młodzieży. Motywacja $i$ realizacja, s. 26.

${ }^{62}$ Tamże, s. 26 i nn;

63 Tamże, s. 1-39.

${ }^{64}$ R. Murawski, Ewangelizacja - katecheza. Świadectwo pierwszych wieków, w: Katecheza ewangelizacyjna. Poszukiwania koncepcji, s. 107-122; W. Osial, Pomiędzy katecheza $w$ parafii a szkolnym nauczaniem religii - z historii katechizacji dzieci i młodzieży w Polsce, „Warszawskie Studia Pastoralne” 11 (2016), nr specjalny, s. 63-81. 
dawniej ewangelizował i katechizował oraz jak dostosowywał przepowiadanie słowa Bożego do zmieniających się warunków społecznych, i jak w ich kontekście rozwiązywał ówczesne problemy, można dokonać trafnej diagnozy i wypracować nowe rozwiązania pastoralne ${ }^{65}$.

Jednocześnie postulują wprowadzenie systematycznej katechezy parafialnej, która nie ograniczałaby się tylko do kilku spotkań przed uroczystością I Komunii św. czy sakramentem bierzmowania ${ }^{66}$. Akcentują przy tym jej mistagogiczny i wspólnotowy wymiar ${ }^{67}$. Zdaniem polskich katechetyków formacja o charakterze katechumenalnym pomaga w pogłębianiu osobistej więzi człowieka z Bogiem i ze wspólnotą Kościoła. Wdraża w życie wspólnoty. Stanowi integralną część katechezy parafialnej, złączonej z sakramentami wtajemniczenia ${ }^{68}$. Nie ogranicza się jedynie do przyjęcia sakramentów inicjacji, ale wiąże z permanentnym procesem wychowania w wierze, w którym istotną rolę odgrywa katecheza rodzinna. Zadaniem duszpasterzy powinna być nieustanna troska o urzeczywistnianie soborowej wizji rodziny chrześcijańskiej. Składają się na nią takie elementy, jak dowartościowanie miłości małżeńskiej, która swoje źródło ma w miłości Bożej, urzeczywistnianie Kościoła domowego (eklezjoli), tworzenie katechumenatu rodzinnego, poprzez słowo i świadectwo chrześcijańskiego życia w rodzinie oraz odkrywanie rodziny jako żywej cząstki wspólnoty lokalnej - parafii, która czuje się za nią odpowiedzialna ${ }^{69}$.

65 Tamże.

${ }^{66} \mathrm{~J}$. Bagrowicz, Inicjacyjno-katechumenalny kształt wychowania religijnego, „Collectanea Theologica” 2002, nr 2, s. 85-108; A. Kiciński, Przygotowanie do sakramentów inicjacji chrześcijańskiej, „Ateneum Kapłańskie” 143 (2004) z. 2, s. 227-237.

67 Trafnie pisze o tym Roman Buchta, powołując się na badaczy historii katechezy. Autor przypomina, że „najważniejszy wkład dla rozwoju nurtu kerygmatycznego a tym samym dla odkrywania istoty mistagogii w katechezie - wnieśli ks. Marian Finke, ks. Franciszek Blachnicki oraz ks. Jan Charytański”. R. Buchta, Mistagogia w polskiej refleksji i praktyce katechetyczno-duszpasterskiej po II Soborze Watykańskim, s. 188; zob. także i por. np. T. Panuś, Konieczność katechezy parafialnej, w: Katecheza parafialna reaktywacja. Duszpasterstwo katechetyczne w parafii, red. R. Chałupniak, J. Kochel, J. Kostorz, Opole 2006, s. 117-128

${ }^{68}$ R. Buchta, Mistagogia w polskiej refleksji i praktyce katechetyczno-duszpasterskiej po II Soborze Watykańskim, s. 27.

${ }^{69}$ R. Chałupniak, Katecheza rodzinna - współczesne wyzwania i realizacja, w: Matrimonio et familiae: $z$ problematyki małżeństwa i rodziny, red. P. Landwójtowicz, 
Wierząca rodzina jest głównym podmiotem katechezy przygotowującej dzieci do I Komunii świętej i młodzieży do bierzmowania. Sama też potrzebuje wsparcia, dlatego słusznie katechetycy zwracają uwagę na konieczność organizowania i prowadzenia w parafiach systematycznej katechezy dorosłych ${ }^{70}$.

Mając na uwadze znaczenie wyżej wymienionych form katechezy parafialnej, badacze wielokrotnie przypominają o znaczeniu liturgii ${ }^{71}$. Słusznie uważają ją za niezbędny element korelacji nauczania religii z katechezą parafialną. Zdaniem polskich badaczy „nie tylko katecheza ma prowadzić do liturgii, ale także liturgia powinna być katechezą"72. Właśnie tak ukierunkowana katecheza otwiera człowieka na Boga, wprowadza $\mathrm{w}$ misterium zbawienia celebrowane $\mathrm{w}$ roku liturgicznym, przygotowuje do świadomego uczestnictwa w celebracjach sakramentalnych oraz wprowadza w tajemnicę i życie Kościoła ${ }^{73}$.

Na tle ogólnego kryzysu wiary i postępującej laicyzacji, słabej moralnie kondycji rodziny i nauczania religii w szkole pozbawionej funkcji wtajemniczenia chrześcijańskiego istnieje potrzeba wdrożenia katechumenatu. Jak pokazuje doświadczenie, jakimś rodzajem katechumenatu dzisiaj są różne ruchy odnowy w Kościele. Te wspólnoty w dużej mierze realizują jego funkcję, ponieważ są w nich wytworzone warunki do przeżycia wszystkich aspektów stawania się chrześcijaninem. Jest więc pedagogia Słowa Bożego, szkoła modlitwy liturgicznej, adoracyjnej, spontanicznej ${ }^{74}$. Ruchy religijne ze swej natury wytwarzają naturalne i głębokie więzi

Opole 2007, s. 145-166; W. Czupryński, Katecheza rodzinna wedtug ks. Franciszka Blachnickiego i jej realizacja w Kościele Domowym, „Studia Warmińskie” 49 (2012), s. 165-180; E. Osewska, Katecheza rodzinna w polskich dokumentach katechetycznych, „Studia nad Rodziną" 2003 nr 1, s. 35-48; J. Stala, Katecheza rodzinna pierwsza i podstawowa forma katechezy, „Paedagogia Christiana” 2002 t. 2, s. 211-217.

70 S. Łabendowicz, Katecheza dorosłych, „Zeszyty Formacji Katechetów” 7 (2007) nr 1, s. 49-56; K. Misiaszek, Katecheza dorostych w funkcji „nawrócenia pastoralnego”, „Warszawskie Studia Pastoralne” 11 (2016) nr specjalny, s. 287-298.

${ }^{71}$ A. Offmański (red.), Współczesna katecheza liturgiczna: liturgia w katechezie i w szkolnym nauczaniu religii, Szczecin 2010, passim.

${ }^{72}$ R. Buchta, Mistagogia w polskiej refleksji i praktyce katechetyczno-duszpasterskiej po II Soborze Watykańskim, s. 204.

73 Tamże.

74 A. Offmański, Katechumenat pochrzcielny..., s. 701. 
pomiędzy ich uczestnikami. Dają poczucie bezpieczeństwa i afirmacji. Są zatem bardzo skutecznym antidotum na współczesne społeczne plagi samotności, bezimienności, egocentryzmu i znieczulicy ${ }^{75}$. Kolejną misją, jaką wypełniają kościelne ruchy religijne, jest nawiązywanie i pogłębianie więzi z Kościołem. Bardzo często wspólnoty religijne, przez swoją ewangelizacyjną aktywność, a jednocześnie jedność z hierarchią kościelną, są jedyną bramą do Kościoła dla tych, którzy przez wiele lat byli poza jego jakimkolwiek duszpasterskim oddziaływaniem. Wyraźnie trzeba stwierdzić, że są one jednym z najlepszych narzędzi ewangelizacyjnych, jakimi dysponuje współczesny Kościół. Są miejscem formacji świeckich misjonarzy i szkołą prawdziwej odpowiedzialności za Kościół. W dobie coraz powszechniejszej krytyki i kontestacji Kościoła, rola ruchów religijnych w tym względzie jest nie do przecenienia ${ }^{76}$.

\section{UWAGI KOŃCOWE}

Z zaprezentowanego przeglądu badań polskich katechetyków wynika, że problematyka korelacji nauczania religii z katechezą parafialną stanowi przedmiot wieloaspektowych analiz. Badacze dostrzegają kryzys tradycyjnego modelu inicjacji chrześcijańskiej w rodzinie i parafii oraz zagrożenia wynikające $\mathrm{z}$ akcentowania kwestii dydaktycznych w nauczaniu religii w polskiej szkole. W tym kontekście, na podstawie trafnie stawianej diagnozy pastoralnej, przypominają o komplementarności funkcji katechezy w posłudze Kościoła. Zwracają uwagę na ewangelizacyjny wymiar szkolnej lekcji religii, mistatgogiczny i wspólnotowy wymiar katechezy parafialnej (także w przestrzeni ruchów i stowarzyszeń kościelnych) oraz na znaczenie katechumenatu rodzinnego. Jednocześnie od dawna proponują różne formy katechezy parafialnej, integralnie powiązane z liturgią, takie jak np. spotkania formacyjne w małych grupach, pielgrzymki, rekolekcje. Priorytetowe znaczenie ma jednak dotarcie do osób, które nie utożsamiają się ze wspólnotą parafialną i nie uczestniczą w lekcjach religii. $\mathrm{Na}$ ten aspekt, jedynie w niniejszym opracowaniu zasygnalizowany, należałoby

75 PDK 11.

${ }^{76}$ J. Mastalski, Grupy, stowarzyszenia i ruchy religijne..., s. 283. 
zwrócić większą uwagę w badaniach, dostrzegając nie tylko taką potrzebę, ale również proponując określone działania pastoralnej.

$\mathrm{Z}$ uwagi na fakt, że charakterystyczną cechą analiz dotyczących korelacji nauczania religii z katechezą parafialną jest odwołanie do posoborowych dokumentów Kościoła, a sporadycznie także do podstawy programowej i programów nauczania religii, warto na tej podstawie zintensyfikować badania empiryczne z zastosowaniem paradygmatu teologii pastoralnej. Pożyteczna dla praktyki jest rzetelnie przeprowadzona diagnoza. Również wzbogacenie analiz o obowiązujące materiały do katechezy parafialnej zasługują na uwagę polskich badaczy. Wnikliwe zbadanie problematyki korelacji nauczania religii $\mathrm{z}$ katechezą parafialną $\mathrm{w}$ różnych pomocach katechetycznych może okazać się znaczące dla wypracowania nowych strategii pastoralnych.

\section{BIBLIOGRAFIA}

Alberich E., Katecheza dzisiaj. Podręcznik katechetyki fundamentalnej, Warszawa 2003.

Bagrowicz J., Inicjacja $i$ katechumenat jako zasada i metoda edukacji religijnej młodzieży, w: Funkcja inicjacyjna katechezy w Kościele wspótczesnym, red. K. Kantowski, Szczecin 2007, 177-198.

Bagrowicz J., Inicjacyjno-katechumenalny kształt wychowania religijnego, „Collectanea Theologica" $2002 \mathrm{nr} 2$, s. 85-108.

Blachnicki F., Formacja służby liturgicznej jako jedna z form młodzieżowego deuterokatechumenatu $w$ parafi, w: Katechumenat. Wspólnoty formacyjne we wspólnocie lokalnej, Biblioteczka animatora, z. 2, Krościenko 2002, s. 28-29.

Buchta R., Mistagogia w polskiej refleksji i praktyce katechetyczno-duszpasterskiej po II Soborze Watykańskim, Katowice 2017.

Chałupniak R., Katecheza rodzinna - wspótczesne wyzwania i realizacja, w: Matrimonio et familiae: $z$ problematyki małżeństwa i rodziny, red. P. Landwójtowicz, Opole 2007, s. $145-166$.

Chałupniak R., Katecheza w stużbie przekazu i formacji wiary. Nowa ewangelizacja ( $w$ nowej) katechezie, „Katecheta” 56 (2012) nr 7-8, s. 4-16.

Chałupniak R., Katecheza w szkole czy poza szkota??, „Paedagogia Christiana” $2012 \mathrm{nr}$ 1, s. 163-178.

Czekalski R., Bibliografia katechetyczna 2001-2010, Warszawa 2012.

Czekalski R., Katecheza komunikacja wiary, Płock 2006.

Czekalski R., Murawski R. (oprac.), Bibliografia katechetyczna 1996-2000, Warszawa 2002. Czupryński W., Katecheza rodzinna wedlug ks. Franciszka Blachnickiego i jej realizacja w Kościele Domowym, „Studia Warmińskie” 49 (2012), s. 165-180. 
Czupryński W., Odnowa parafii i duszpasterstwa. Deuterokatechumenalna koncepcja chrześcijańskiej formacji w myśli i dziele ks. Franciszka Blachnickiego, Olsztyn 2011.

Dziekoński S. (red.), Ewangelizować czy katechizować?, Warszawa 2002.

Dziekoński S., Katecheza inicjacyjna w Polsce - rzeczywistość i oczekiwania, w: Funkcja inicjacyjna katechezy w Kościele współczesnym, red. K. Kantowski, Szczecin 2007, s. $97-112$.

Dziekoński S., Korelacja wychowania w rodzinie, parafi, szkole - potrzeba i możliwości, w: Rodzina - Szkoła - Kościót. Korelacja i dialog, red. P. Tomasik, Warszawa 2003, s. 27-46.

Dziekoński S., Specyfika chrześcijańskiego wychowania w rodzinie, w: Wychowanie chrześcijańskie. Między tradycją a wspótczesnością, red. A. Rynio, Lublin 2007, s. 700-701.

Iwaniuk H., Nauka religii $w$ szkole a katecheza parafialna, „Ateneum Kapłańskie” 571 (2004), s. 450-466.

Kantowski K., (red.), Katecheza w parafii. Poszukiwanie tożsamości, Warszawa 2004.

Kiciński A., Przygotowanie do sakramentów inicjacji chrześcijańskiej, „Ateneum Kapłańskie" 143 (2004) z. 2, s. 227-237.

Kochel J., Lekcja religii szansa dla ewangelizacji, „Polonia Sacra” 22 (2018) nr 2 (51), s. 19-39. DOI: http://dx.doi.org/10.15633/ps.2498.

Konferencja Episkopatu Polski, Dyrektorium katechetyczne Kościoła katolickiego w Polsce, Warszawa 2001.

Koseła K., Religia przy tablicy - postawy wobec lekcji religii w szkołach, w: Szkoła czy parafia? Nauka religii $w$ szkole $w$ świetle badań empirycznych, red. K. Kiciński. K. Koseła, W. Pawlik, Kraków 1995, s. 90-105.

Kujawin W., Parafialne duszpasterstwo katechetyczne w optyce magisterium Kościoła, „Eódzkie Studia Teologiczne” 23 (2014), s. 25-37.

Łabendowicz S., Katecheza dorostych, „Zeszyty Formacji Katechetów” 7 (2007) nr 1, s. $49-56$.

Łabendowicz S., Wychowanie chrześcijańskie w katechezie szkolnej, „Roczniki Pedagogiczne" 8 (2016) nr 2, s. 49-76. DOI: http://dx.doi.org/10.18290/rped.2016.8(44).2-4.

Mastalski J., Grupy, stowarzyszenia i ruchy religijne dla młodzieży w służbie katechezy, „Ateneum Kapłańskie” 573 (2004), s. 278-289.

Mąkosa P. (red.), Katecheza ewangelizacyjna. Poszukiwania koncepcji, Lublin 2010.

Mąkosa P. (red.), Nowa ewangelizacja w nowej katechezie, Rzeszów 2013.

Mąkosa P., Ewangelizacyjny wymiar katechezy [online], [dostęp: 12.01.2019 r.], s. 1-10, $<$ https://depot.ceon.pl/bitstream/handle/123456789/3627/Ewangelizacyjny\%20 wymiar\%20katechezy.pdf? sequence $=3>$.

Mąkosa P., Systematyczna katecheza parafialna dzieci i młodzieży. Motywacja i realizacja [online], [dostęp: 22.01 .2019 r.], s. 1-39, <https://depot.ceon.pl/bitstream/handle/123456789/3177/Systematyczna\%20katecheza\%20parafialna\%20dzieci\%20i\%20 m\%C5\%82odzie\%C5\%BCy.\%20Motywacja\%20i\%20realizacja.pdf?sequence=1>.

Misiaszek K., Co z katecheza parafialna w Kościele w Polsce?, „Studia Pastoralne” 13 (2017) nr 13, s. 87-97. 
Misiaszek K., Formacja katechetów, „Ateneum Kapłańskie” 84 (1992) z. 2, s. 265-274.

Misiaszek K., Katecheza dorosłych w funkcji „nawrócenia pastoralnego”, „Warszawskie Studia Pastoralne" 11 (2016) nr specjalny, s. 287-298.

Misiaszek K., Katecheza parafialna - rzeczywistość i oczekiwania, w: Komunikacja wiary $w$ trzecim tysiącleciu, red. S. Dziekoński, Olecko 2000, s. 63-74.

Misiaszek K., Koncepcja nauczania religii katolickiej w publicznej szkole polskiej, Warszawa 2010.

Misiaszek K., Misja prorocka i jej realizacja w Kościele w Polsce, „Teologia Praktyczna” 8 (2007), s. 7-17.

Misiaszek K., Mistagogia $w$ katechezie, w: Mistagogia a duchowość, red. A. Żądło, Katowice 2004, s. 81-90.

Misiaszek K., Potrzeby i możliwości wprowadzenia elementów ewangelizacji do nauczania religii $w$ szkole, w: Katecheza ewangelizacyjna $w$ rodzinie, parafii, szkole, red. S. Dziekoński, Warszawa 2002, s. 173-184.

Misiaszek K., Wspólnota chrześcijańska (parafia) jako podmiot katechezy, w: Katecheza w parafii. Poszukiwanie tożsamości, red. K. Kantowski, Warszawa 2004, s. 17-27.

Misiaszek K., Wyzwania wspótczesności dla formacji katechetów, „Ateneum Kapłańskie” 86 (1994) z. 2-3, s. 203-214.

Młyńska E., Ewangelizacyjny wymiar katechezy parafialnej, w: Katecheza ewangelizacyjna w rodzinie, parafii, szkole, red. S. Dziekoński, Warszawa 2002, s. 115-138.

Murawski R., Czekalski R., Tochmański J. (oprac.), Bibliografia katechetyczna 1945-1995, Warszawa 1999.

Murawski R., Działania katechetyczne w parafii w świetle Dyrektorium Ogólnego i Polskiego, w: Przesłanie dokumentów katechetycznych Kościoła w Polsce, red. S. Dziekoński, Warszawa 2002, 55-70.

Murawski R., Ewangelizacja - katecheza. Świadectwo pierwszych wieków, w: Katecheza ewangelizacyjna. Poszukiwania koncepcji, red. P. Mąkosa, Lublin 2010, s. 107-122.

Offmański A. (red.), Współczesna katecheza liturgiczna: liturgia w katechezie i w szkolnym nauczaniu religii, Szczecin 2010.

Offmański A., Katechumenat pochrzcielny wzorcem nauczania religii i katechezy ewangelizacyjnej, w: Septuaginta pedagogiczno-katechetyczna, red. A. Walulik, J. Mółka, Kraków 2017, s. 696-722.

Offmański A., Katechumenat pochrzcielny wzorcem nauczania religii i katechezy ewangelizacyjnej, w: Septuaginta pedagogiczno-katechetyczna, red. A. Walulik, J. Mółka, Kraków 2017, s. 696-722.

Offmański A., Model katechezy ewangelizacyjnej w dokumentach Kościoła, w: Ewangelizować czy katechizować?, red. S. Dziekoński, Warszawa 2002, s. 53-72.

Osewska E., Katecheza rodzinna w polskich dokumentach katechetycznych, „Studia nad Rodziną" 2003 nr 1, s. 35-48.

Osial W., Pomiędzy katecheza $w$ parafii a szkolnym nauczaniem religii - z historii katechizacji dzieci i młodzieży w Polsce, „Warszawskie Studia Pastoralne” 11 (2016), nr specjalny, s. 63-81. 
Panuś T., Konieczność katechezy parafialnej, w: Katecheza parafialna - reaktywacja. Duszpasterstwo katechetyczne w parafii, red. R. Chałupniak, J. Kochel, J. Kostorz, Opole 2006, s. 117-128.

Panuś T., Parafia uprzywilejowanym miejscem dla katechezy przygotowującej do sakramentu dojrzałości chrześcijańskiej. Doświadczenia krakowskie, w: Dzisiejszy bierzmowany. Problemy i wyzwania, red. J. Stala, Kielce 2005, s. 257-280.

Panuś T., Potrzeba katechezy parafialnej, „Ateneum Kapłańskie” 96 (2004) z. 573, s. 212-226.

Pełka F., Uwarunkowania społeczne katechumenatu, „Ateneum Kapłańskie” 70 (1977), s. 216-220.

Podsiad A., Słownik terminów i pojęć filozoficznych, Warszawa 2000.

Potocki A., Ewangelizacyjna katecheza młodzieżowa z perspektywy paradygmatów teologii pastoralnej, w: Katecheza ewangelizacyjna. Poszukiwania koncepcji, red. P. Mąkosa, Lublin 2010, s. 123-144.

Potocki A., Katecheza między niebem a ziemiq - między parafia a szkoła, „Katecheta” 45(2001) nr 2, s. 13-22.

Potocki A., Katecheza w szkole jako problem duszpasterski, „Homo Dei” 62 (1993) nr 3, s. $48-59$.

Potocki A., O Kościele także socjologicznie, Warszawa 2017.

Potocki A., Parafia - podmiotem i miejscem katechezy, „Perspectiva: Legnickie Studia Teologiczno-Historyczne" 5 (2006) nr 2, s. 84-100.

Potocki A., Polemiki wokół powrotu religii do państwowego systemu oświaty, „Ateneum Kapłańskie” 84 (1992) z. 2, s. 221-232.

Sobór Watykański II, Dekret o misyjnej działalności Kościoła „Ad gentes divinitus” (7.12.1965), w: Sobór Watykański II, Konstytucje, dekrety, deklaracje, Tekst polski, Nowe tłumaczenie, Poznań 19863, s. 433-471.

Stala J., Katecheza rodzinna pierwsza i podstawowa forma katechezy, „Paedagogia Christiana" 2002, t. 2, s. 211-217.

Tomasik P., Ewangelizacyjne formy katechezy w kontekście wezwania do nawrócenia, „Studia Theologica Varsaviensia” 2 (2014), s. 103-129.

Tomasik P., Katecheza Kościoła w Polsce wobec nowej ewangelizacji, „Verbum Vitae” 21 (2012), s. 273-296.

Tomasik P., Lekcja religii katolickiej: wybór między dwiema skrajnościami, „Katecheta” 43 (1999) nr 7-8 s. 92-95.

Tomasik P., Możliwości ewangelizacji w szkolnym nauczaniu religii, w: Katecheza ewangelizacyjna. Poszukiwania koncepcji, red. P. Makosa, Lublin 2010, s. 63-80.

Zając M. (red.), Katecheza w parafii, Lublin 2016. 